\title{
Managing in a war zone: Somalian managers in the banking and mobile telecommunications sectors
}

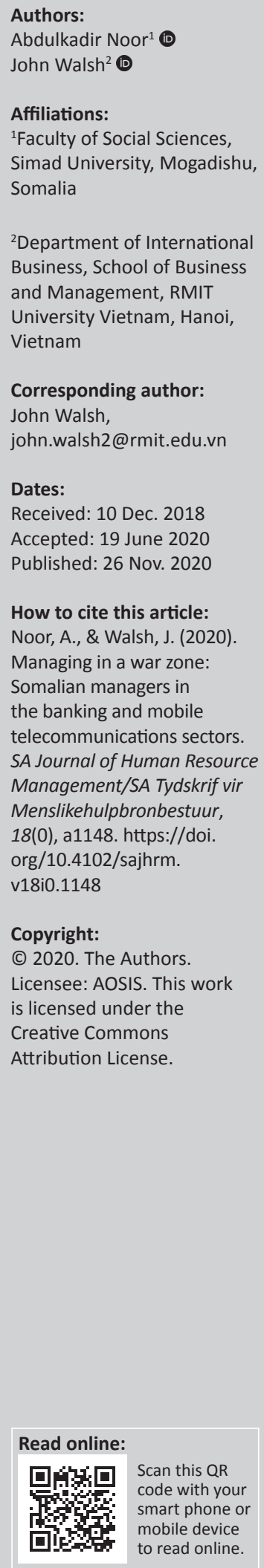

Orientation: Management studies too often concentrate on supposedly normal market conditions in stable, developed countries. In reality, most forms of management are conducted in more trying circumstances, and this article seeks to expand knowledge of how it takes place under difficult conditions.

Research purpose: This study explored management techniques under wartime conditions exhibited by managers in the banking and mobile telecommunications sectors in Mogadishu, the capital of Somalia.

Motivation for the study: Somalia is a fragile state that risks failing its people in many ways, including security, food security and basic public services. One means of compensating for these failures is the private sector's ability to organise not just business but essential public services when the government is unable to do so. This article studied whether that was taking place.

Research approach/design and method: The research was qualitative in nature and featured in-depth, personal interviews with managers and executives in the identified sectors of interest. Respondents were identified through convenience and then purposive snowball sampling techniques.

Main findings: It was found that adaptations to managing in wartime could be divided into three main themes: practical aspects of managing in adversity, coping mechanisms and the ethical issues involved in managing without a government. In general, in the absence of a legitimate ruling power or a form of market regulation, managers reverted to the pre-existing tribal system as a means not just of managing transactions but also to instil trust in those transactions.

Practical/managerial implications: A model is provided for managing under wartime or similarly difficult situations, which might be adapted to other contexts.

Contribution/value-add: This article extends knowledge of how management is conducted in wartime and how managers adapt to adverse conditions.

Keywords: banking; conflict; mobile telecommunications; resilience; Somalia.

\section{Introduction}

Somalia, a coastal country located on the Horn of Africa, has had a troubled history since emerging from Italian and British imperialism as the Somali Republic in 1960. A military coup in 1969 was succeeded by a civil war in the 1990s that led to the evisceration of the country's institutions, such that it became considered a 'failed state'. This concept, much contested, places the reasons for failure on crises that are local in nature and the failure of local leaders, whilst in reality it is the 'imperial history of global capitalism' that is the principal cause and this is manifested locally as the crisis that is manifested locally (Jones, 2008). This crisis, of course, results from the uneven development that drives the spread of capitalism through colonialism. It resulted in the breakdown of the central state and the rule of law. In place of the central state, local communities reverted to traditional or religious systems that had served them in the precolonial era. Commercial operations were, necessarily, severely hampered in these circumstances because there was no guarantee of property rights or of normal banking activities. In addition, there is, of course, the relentless violence and the disruption this causes. The violence has been intensified by the fact that '... covert commandos and drone strikes assisted by a secret CIA base in Mogadishu, are routine' (Anderson, 2017). Famine, or the threat of famine for a large proportion of the population, has become a persistent presence (Samator, 1992).

In some cases, failed state status obscures the fact that some societies never really had successful or sustainable institutions and, instead, relied principally upon patronage networks and the 
need to endure factionalism (Englebert \& Tull, 2008). In the case of Somalia, this has meant the re-emergence of the tribal structure and system that were so influential for so long. The complex tribal system, featuring community selfrule in hierarchical societies, many nomadic, can merge into a hybridised form of non-centralised government through those involved applying leverage from their position to obtain a form of pragmatically permitted legitimacy: 'The local dynamics of state-building are shaped mainly by the reproduction modes and legitimisation strategies of local elites who use the appropriation of material and immaterial (e.g. reputation) resources not only for enriching themselves, but also for securing legitimacy from relevant segments of the population (Debiel, Glasner, Schetter, \& Terlinden, 2009).' In doing so, they come into competition or conflict with those whose legitimacy has derived from other sources, such as political party office holding, traditional and religious authorities, influential intellectuals, diaspora repatriates and so forth. Not only will these elite representatives compete for political power, but they may also be competing for different conceptions of how the economy and the actors within it should behave. Business operators and their employees may face deep contradictions in terms of how they can survive from day to day and have their businesses thrive in hostile environmental change. These problems are notable for two business sectors that are considered to be essential in contemporary society for both the business-to-customer (B2C) and business-to-business (B2B) sectors: banking and mobile telecommunications. Not only are these essential to the prevailing economic and social conditions, but they may become even more important in the absence of state institutions. People must still live, of course, and so they need to transfer money to relatives and other people who need to buy food and other necessities and to have trusted intermediaries ensure daily security in the absence of the rule of law. The concept of the 'failed state' is not helpful for those bodies responsible for delivering aid and assistance to local communities because, by declaring that no groups or individuals possess sufficient legitimacy, no assistance can be delivered with the required level of accountability. This is one of the motives behind the creation of the 'fragile state' definition, which encompasses a wider range of causal factors than conflict or poverty in recognising that there is in fact considerable intersectionality of causation: 'Violent conflict has sparked dramatically since 2010, and the fragility landscape is becoming more complex. Climate change, rising inequality, demographic change, new technologies, illicit financial flows and other global trends may also create fragility risks. Both low- and middle-income countries are affected by fragility risks, some far away from where the problems start' (World Bank, 2018). In this regard, Somalia is considered to be one of those countries that may be included in the category of suffering fragility, conflict and violence (FCV), although it is possible to argue that other designations, including 'failed state' and 'hybrid state' might also be employed. The term 'fragile or failed state' will be used to designate this plurality of usage.
This article reports on a programme of qualitative research conducted in Somalia amongst cohorts of people in the banking and mobile telecommunications sectors with a view to answering the identified research questions. The article continues with a literature review of relevant subjects, a description of the research method employed, a presentation of the findings and a discussion of these findings, before ending with concluding notes. The purpose of the article is to provide a tentative model of management in wartime that helps to explain the behaviour of managers in the defined sectors in the research site of Mogadishu.

\section{Literature review}

Much remains to be learned about business activities in failed or fragile states, not least because of the difficulties inherent in conducting worldwide research in such situations and in the complex and intricate interactions between many variables that make each situation appear to be unique. In these circumstances, it has been difficult to generalise with any confidence, and many areas of vagueness remain. When empirical research has been conducted in Somalia, with respect to business or management issues, it tends to have been restricted to sites of relative security (e.g. Ali \& Dahie, 2015; Ali, Sidow, \& Gueid, 2015), although this has not always been the case (Sayid, Echchabi, \& Aziz, 2012). Larger scale studies of reconstruction issues by international aid donors and similar bodies have been able to collect data in fragile and failed states, but they have been able to deploy resources on a completely different level to the research considered in this article. Instead, the research here focuses specifically on management issues in specific business sectors in a specific part of the country where conducting research as an academic researcher was possible.

Crisis management approaches exist within the changed circumstances that then apply and evolve so as to be able to cope with them. Recognising that life must continue at some level even during wartime, both sides of a civil war will, explicitly or implicitly, make accommodations for the civilian population in whose name they launch their campaigns so that they are not destroyed because of the conflict: 'Bargains, deals, and tacit understandings between states and insurgents are common in civil wars' (Staniland, 2012). In other words, business managers will be made aware of those areas in which they will be allowed to conduct their activities as normal and those areas in which they will be expected to cooperate with the dominant local power or even to devote all their resources to the military effort. This suggests a three-part approach to understanding the practice of management during wartime: understanding how businesses can survive at all in such difficult circumstances, how and when managers must make arrangements with the dominant power and what are the ethical issues involved when managers must act in direct support of a wartime effort. It is understood that these issues are complicated in the case of a civil war because the cause of conflict may involve identity issues that are fluid and contested and because, when the 
war does stop, the people fighting it and enduring it will still be living side by side (Wehr \& Lederach, 1991).

\section{Managing in adversity}

Management literature tends to focus on the ability of people and organisations to continue with business on a basis as close as possible to normal, no matter what the circumstances. To achieve this, it is considered that organisations should demonstrate resilience. In the context of dealing with more common and severe adverse weather events, Linnenluecke, Griffiths and Winn (2012) consider resilience to be the '... capacity to absorb the impact and recover from the occurrence' of unwelcome events, which is tied to the need for anticipating adaptation. Annarelli and Nonino (2016) identify a wide range of fields in which the term 'organizational resilience' is used and identify different directions and fields of inquiry in which the concept is being pursued.

Organisations need to develop the building blocks of resilience during normal working conditions so that preparation for difficult conditions takes place before the crisis requires it (Aleksić, Stefanović, Arsovski, \& Tadić, 2013). Lengnick-Hall, Beck and Lengnick-Hall (2011), meanwhile, consider resilience to be centred upon the ability of individuals to be able to respond to adversity appropriately:

\begin{abstract}
... [A]n organization's capacity for resilience is developed through strategically managing human resources to create competencies among core employees, that when aggregated at the organizational level, makes it possible for organizations to achieve the ability to respond in a resilient manner when they experience severe shocks. (p. 247)
\end{abstract}

The nature of work and the way that work is managed also has a significant impact on the degree of resilience. Defining resilience in part as the ability to be responsive to change in a positive way, Mallak (1998) observes that ' $[a]$ s workers become more empowered, more decisions are often made without immediate approval and under time pressure'. It would be expected, therefore, that some types of business activity, where employees are routinely able to take decisions based on their own initiative and discretion, would tend to encourage a degree of innate resilience.

There is also an external element to developing resilience because evidence indicates that people in high-trust societies are more likely to be able to demonstrate the flexibility necessary to respond well to a crisis (Levine, Lin, \& Xie, 2018). It has also been indicated that, in the case of banks, smaller organisations are more likely to be able to survive adversity (Vallascas \& Keasey, 2012).

In short, organisational resilience is a complex phenomenon that consists of both internal and external elements and that can be developed and encouraged to a certain extent. However, it is likely that organisations that are well resourced and that inhabit economies with high levels of information and competence are more likely to be able to demonstrate resilience.

\section{Coping mechanisms}

Previous research (Nenova \& Harford, 2005) has indicated that Somali organisations have used a variety of methods to try to cope with the disruptions to normal business life. These include accepting external assistance from international telecommunications companies, making local agreements to deal with interoperability issues and the use of informal systems such as hawala to handle international payments. Hawala is a trust-based system used in a number of Muslimmajority societies in which money can be deposited with a local agent in one country and then withdrawn from an agent in another country if the applicant is able to answer a number of relationship-based questions that only a person with the requisite tribal knowledge could answer (Nenova \& Harford, 2005). It was anticipated that similar forms of coping mechanisms would be witnessed in the current research. This is particularly true in the case of those occasions when businesses operated in those areas in which cooperation with realpolitik was required because of a deal made with one of the warring powers. The state, of course, can lay monopolistic claim to the legitimate use of violence, but this claim does not extend to the case of a civil war, in which a non-state actor can claim effective power within a territory and can back that claim with the threat of violence. Management under duress can depend on decision-making based on a wide variety of forms and bodies of knowledge and experience, and individuals will necessarily vary in this regard (Hoekstra \& Montz, 2017).

This situation can give rise to a form of cowboy capitalism, in which the fact that lawful authorities are absent and replaced by quasi-state authorities means that legal decisions are usually delivered through the barrel of a gun (e.g. Walsh, 2012, 2016). This can occur when the legitimate state's institutions are not able to function in a particular place or have been suborned by non-state actors so that they are no longer active. A range of different such situations can exist in a civil war because the state might be able to control some parts of a city, for example, although not other parts. This might take place on a vertical as well as a horizontal level, as demonstrated by recent US military doctrine, which privileges control of the air through manned and unmanned vehicles rather than, as the saying has it, 'boots on the ground' (Renner, 2004).

The effect of occupation - actual or threatened - has been studied under various perspectives. It is common to argue in such cases that businesses in these circumstances should follow the lead of civic institutions in promoting self-reliance and self-development and that, inevitably, such institutions should also be working towards political change in the name of the people (Kuttab, 1989). However, in the case of business, attempts to continue management activities on as close to a normal standard as possible have almost invariably been labelled as 'collaboration' throughout history because they are seen as benefitting the occupying army. This inevitably introduces an ethical component: 'Every culture tags collaboration as moral failure. What could otherwise be 
described simply as the political arrangement of dependency under the conditions of military occupation is almost never permitted to remain simple or purely descriptive' (Brook, 2007 , p. 4). There have, in other words, been few attempts to try to isolate from a non-moralistic viewpoint to determine which aspects of management under occupation are legitimate forms of business as (un)usual and which have been repurposed to the benefit of an occupying force. This article hopes to contribute to this gap in knowledge.

\section{Ethical issues}

The previous section indicated that the literature has tended to conflate operational and ethical aspects of behaviour when it comes to business under occupation. However, there is another aspect to this conflation and that is to consider business management ethics from a stakeholder perspective. This approach implicitly or explicitly assumes that stakeholders have a right to some kind of guarantee of their rights with respect to the company concerned and that the latter acts through the accepted provision of a social contract (Kakabadse, Rozuel, \& Lee-Davies, 2005).

In complex situations, companies can variously engage and disengage with particular stakeholders as circumstances change (Lehtinen, Aaltonen, \& Rajula, 2019), indicating that a similar approach, perhaps in a more extreme form, might be adopted in wartime. Because the conflict is not continuous, it might be possible to re-establish business activities through network reformation at a time when it is possible so to do.

In the current research, the banking and mobile telecommunications sectors were explored. It might be argued that these activities are essential to the functioning of a normal society and that providers have a moral duty to provide such services when they can do so. This is problematic from a methodological perspective because so much has been developed from a Western viewpoint, derived from Greek and Latin philosophers, whose work was then built upon by Islamic thinkers, whose ideas are not always captured in management literature. It is also the case that there is not just one Islamist ethic, although all are rooted in the same core beliefs. The founding points are the Quran and the person of the Prophet himself, who was of course a merchant. Together, they indicate this foundation:

\footnotetext{
... [T] he utmost importance of all sorts of productive work and the distribution of wealth in society; the vocation of trade; the fundamental principles of freedom and justice for business conduct; the prescription of certain manners such as leniency, service-motive, and consciousness of Allah; and mutual consultation. (Abeng, 1997:47-54)
}

Clearly, there is an extensive overlap with the stakeholder approach, and both could be used to demonstrate that business should go ahead for the benefit of different sectors of society whenever it can do so. This research will aim to make a contribution to understanding the extent to which these values can be detected under difficult conditions.

\section{Methodology}

This project employed qualitative research for data collection. A qualitative approach was selected for both ideological and practical reasons. From the ideological perspective, qualitative approaches have been found to be helpful in outlining the location-specific factors and contexts that are prevalent and their interactions with specific interventions with different sectors of the population (Nastasi \& Schensul, 2005).

In doing so, it is recognised that, as Bourdieu claimed, the proper focus of social inquiry is not the individual; although independent people are important and to be valued, '... it is the field which is primary and must be the focus of the research operations' (Bourdieu \& Wacquant, 1992, p. 107) in which people are 'agents' who provide the texts by which the reality of social relations and social reproduction may be understood (Bourdieu, 1998, pp. 22-23). It is necessary to locate the field within the overarching power structures that configure the lives of people and then seek to understand the habitus that individuals derive and develop. In this regard, the habitus is the long-standing schemas and system of dispositions that people understand as reflecting their progress in the wider world. The Somalian environment has caused considerable stress and anxiety to the people who occupy it, and the disruptions have been of sufficient length and importance to ensure that the habitus of each individual has become suffused by these events. Moving from the ideological to the practical, therefore, it is important to appreciate the stress that people may be feeling and the diversity of impacts and outcomes that may have resulted from it. Consequently, it is appropriate to permit individuals the opportunity to express themselves as they see fit and not seek arbitrarily to restrict their responses too narrowly in the way that a quantitative survey would have done.

In this research, then, a series of face-to-face interviews was conducted with respondents in the banking and telecommunications sectors. Respondents were identified using a combination of convenience, purposive and snowball sampling. The first respondents were identified through personal networks and connections, and these respondents were invited to identify future additional respondents who might be contacted. The purposive element of this approach involved attempts to introduce some diversity into the sample achieved. Given the nature of Somali society, all respondents were men with a similar economic and social background appropriate to the work position in which they found themselves. This provides an inevitable limit on the amount of heterogeneity it was possible to achieve in a sample and creates issues that need to be recognised in the data analysis process (Robinson, 2014). Interviewing was continued until the point of saturation was reached - that is, when the researchers realised that adding new interview transcripts was not adding any new information. Under these circumstances, the interviewing process was ended. At this point, the researchers concluded that they possessed sufficient data that were rich (i.e. in quality of responses) and 
thick (i.e. in quantity of responses) so as to believe that the saturation point had been reached (Fusch \& Ness, 2015).

A semi-structured interview schedule was created that enabled individual conversations to vary according to the types of communications that respondents wished to make whilst still having an overall framework to keep the conversation as relevant as possible to the research themes. The semi-structured schedule was devised after consultation of the secondary literature and through a period of personal observation of the environment. Somali and Arabic were the languages used for interviewing. The interviews were translated into English and transcribed for future analysis. The transcripts were entered into a database, which also contained the secondary literature and the contents of the research diary, which is a document that contains both observations made during the field research and subsequent reflections upon those observations. The contents of the database as a whole were subjected to a process of content analysis. Conventional content analysis was employed, in which codes and themes were derived directly from the texts explored, although, in considering the configuration of the discussion section, elements of directed content analysis were also used, in which specific words and concepts were sought (Hsieh \& Shannon, 2005).

Overall, 30 interviews were conducted with representatives of the banking sector, and 22 interviews were conducted with representatives of the telecommunications sector. All of the respondents were men with formal education and experience in the private sector. The respondents were generally junior or middle-level managers, although some were more senior. All respondents were located in the capital city, Mogadishu, because for security reasons it was not feasible to interview people from locations outside the city. It is clear that there are research limitations in the case of this research in terms of both time and space. These were unavoidably constrained by interests of personal safety. If circumstances permit, longitudinal research projects might be launched to evaluate the conclusions drawn here by considering them over a longer period of time.

\section{Findings}

'People view business as the sole source of authority to help them survive in the absence of the rule of law.' (Telecommunications sector respondent, 42, Manager, 13)

There is no doubt that the respondents felt that the lack of security caused by the absence of the rule of law was the central issue that affected their working lives. They felt that they faced the 'law of the jungle' and could not be sure what kinds of conditions they would face from one day to the next. There might be fairly stable conditions, but there might well be fighting or the aftermath of fighting that has caused the closing of roads and businesses without notice. Surviving these conditions entailed being able and willing to respond to a volatile environment on a continual basis, shifting plans where necessary and dealing with the stress that such conditions would bring. It is very difficult to plan for normal business activities in this case. In extreme and tragic cases, a staff member might have been wounded or even killed, which would also interrupt business plans, in addition to the human cost. Where resilience has been shown on the individual and organisational levels, this appears to have resulted from the efforts and abilities of individual people who have been able to react to and adapt to change in a positive way. The organisations themselves do not seem to have much in the way of institutional ability to cope beyond the capabilities of talented individuals. These findings are broadly in line with the concept of companies engaging and disengaging with stakeholders in response to changes in the external environment described previously.

The impact of the absence of the rule of law may be seen in terms of business activities and in terms of social impacts.

\section{Business activities}

Lawlessness means that most standard practices have either to be suspended or rearranged. It is not possible to offer banking services or telecommunication services when no one can be sure whether or not shops and businesses will be open or closed the next day. Attempting to maintain regular daily schedules cannot be managed, and it is necessary to be flexible in order to achieve anything. Managers need to take responsibility for freeing stakeholders from meeting strict schedules when there are acts of God that are beyond their control. It is unrealistic to expect bills always to be paid on time, for example, whilst any aspirations to lean logistical systems are impractical. Under such circumstances, the importance of trust in relationships assumes even greater importance because it can easily appear that a stakeholder is failing to meet contractual obligations when the reality is that meeting the obligation is just not possible. This is in line with Islamic ethics in business, which makes the claim that its role in maintaining social relations is an ethical action. Distribution and redistribution of wealth within an economy cannot take place if businesses are closed. Trust helps to persuade stakeholders that the business will continue as soon as possible and under whatever circumstances may be available.

It would, further, be quite possible for unscrupulous people to take advantage of the confusion to obtain benefits for themselves if no conditions of trust existed. A proper understanding of the relationships between the stakeholders involved would help in measuring and monitoring performance and policies, and this would be invaluable. For example, one respondent observed rather luridly: 'In a country where there is no effective law and order, the problems are uncountable. Competitors can do whatever they want to you, they can even assassinate you'. Mohamed Mahamoud Sheik, a young entrepreneur who opened Somalia's first florist shop and first laundry and dry cleaning business since 1991, was murdered by unknown assailants for unknown reasons (Marchese \& Ratcliffe, 2018). It is certainly possible that personal or business motivations may have become involved in the terrorist and politically 
motivated attacks in the country. In other words, even if there are the implicit deals and compromises made by the warring parties and the people suggested previously, then the situation can still be chaotic and the terms and conditions subject to asymmetrical information availability.

Smooth operation of services is not possible in these circumstances, and it seems inevitable that consistency of operations and service provision will also be compromised. In this case, it is the relationship between service provider and customer that will need to be flexible and based on trust and a commitment to moving towards the establishment of a long-term relationship. This is more commonly found in the banking sector rather than the telecommunications sector. Loyalty to banks - or, at least, reluctance to switch (e.g. Hauff, 2019) - is reported to be high, whilst customers of mobile telecommunications are more willing to change from one brand to another depending on short-term considerations such as discount pricing or free services, as well as to take advantage of different forms of network externalities that will change in time. Churn amongst telecommunications customers might be increased in the conditions outlined here because services are likely to be affected on a differential basis, and so consumers would be likely to try to use multiple channels so as to increase their options in the event of discontinued services. Whilst this might also be possible for bank customers, it is generally not so easy to do the equivalent of switching a subscriber identification module (SIM) card in order to respond to changing short-term conditions. The opening of access to submarine fibre optic cables in 2017, delayed because of concerns about piracy, as well as the creation of a new legal framework, have offered some new structure to a situation that had been termed 'anarchy' (Business Wire, 2019). However, these new capabilities are not placed in the hands of a competent central state but as something of a prize to be competed for by the various actors in the civil war. This has not, in other words, changed the terms of the game so much as added stakes to the existing game.

Because conditions militate against the formation of business relationships on the rational basis of standard trust establishment, practitioners have instead resorted to tribal loyalties as a basis for making business decisions. Whilst this is a reasonable response to the situation encountered, and it is one that is generally well understood by the people involved, it is contrary to the principles of business practice that have been inculcated into the respondents through their business practice and education. This is very evident in the discourse employed. Many respondents spoke repeatedly about desirable business approaches, such as 'good governance, transparency, justice and giving everyone their rights' or ' $\ldots$ our business success depends on having qualified and skilled staff who serve customers honestly'. However, whilst these qualities remain important, they are undermined by the reality that tribal relations have resumed their importance in business relationships, and these relations are often opaque in nature and may seem unfair to other people because the meritocracy of rational business management is replaced by an alternate logic. Managers are required to adjust through coping mechanisms to deal with these conditions but also act with respect to the ethical position that they are obliged to pursue. The tribal system is both a means of coping with difficult circumstances and a replacement system when regular capitalist relations become unsustainable.

Respondents did not openly acknowledge the disparity between discourse and practice. Instead, it became evident in their answers to different types of prompting that they wanted and expected to operate in organisations that were rational and understandable through management logic, but they actually lived in quite a different world. This has resulted in a form of cognitive dissonance that might also contribute to stress and alienation. One banking sector respondent observed that ' $[p]$ eople view business as the only instrument that will help them survive, and give all their efforts to making businesses and gaining profits'. In this case, business success becomes the sole means of survival rather than being just one part of a life that has a balance of different institutions and interests. It indicates the personal difficulties involved in adapting to coping mechanisms. The switch might appear to be logical, but it can remain a complex one for individuals to negotiate nevertheless.

From a practical perspective, the absence of a central banking system in addition to the central institutions of security mean that individual banks are obliged to act as independent units offering needed services to customers without the support of the usual banking infrastructure. People still need to transfer funds to each other to meet daily needs, to receive remittance from diaspora and overseas workers, and to pay bills and debts. In the absence of the banking infrastructure, banks provide their own services and microfinance services with the assistance of mobile telecommunications and the willingness to innovate and be flexible in operations noted above. Even so, the amount of risk borne by individual banks doing this increases significantly. However, this falls within the realm of ethical imperatives in that other stakeholders rely upon businesses to keep their activities going for the good of the social system as a whole.

A further example of changes to business practice caused by external conditions is through the rise of informal employment, particularly in the telecommunications sector. Because it cannot always be predicted accurately what kind of activities might be possible the next day, some managers have started the practice of hiring casual labour wherever circumstances indicate that such an opportunity exists. This is, again, contrary to normal managerial practice as business education might dictate, although it is, nevertheless, a rational response to a short-term problem. It is assumed that managers will dispense with the usual documentation in such cases, not least because the absence of state institutions means that tax is no longer being collected and auditing and monitoring functions have ceased. It is evident that both coping and ethical issues are involved in this case. 


\section{Social impacts}

That normal institutional rule has broken down and community relations have in part replaced it also has a social impact. Dealing with elders places business practitioners in different types of relationships with community members. Where previously the balance of power in the relationship would be with the person holding the office or who is in possession of the desired resources, now the balance of power changes according to other criteria. In the case of the banking sector, it is the banker rather than the customer who tends to hold the upper hand in the relationship, but the opposite is the case for telecommunications, because customers have a range of options (albeit sometimes a narrow range) from which to choose. Now, the situation is different in that the relevant resources are societal in nature and relate to familial and tribal relationships. As ever, a measure of gerontology is in place whereby the elderly expect to be able to rule over the younger people. In such a case, business education at the undergraduate or the graduate level assumes rather less importance than it would have done under the rule of law. This also has the effect that the business thinking and business-style discourse that respondents prefer to use is reduced in value because it is not the basis on which community elders choose to make their decisions. Again, these are examples of how respondents have used a previous system as a form of temporary coping mechanism whilst also being willing to use it as a replacement system altogether if that proves necessary.

A number of respondents spoke about working in the national interest and representing the people when government has become ineffective. In this sense, the private sector has replaced the public sector in representing the interest of the people. Several respondents spoke about the sense of responsibility they felt for propping up private sector organisations generally acting independently. As one respondent in the telecommunications sector put it:

The creation of this business was based on two main objectives: the first was to serve the people and the second was to make profits, so it was in everyone's mutual interest that we be successful.

This respondent continued by talking about working in collaboration with the people who have settled in the city. His company provides good services to the people and also employs some of them, which means that they will have more income to spend. There is, therefore, even a measure of redistribution in the way that the private sector has replaced the public sector. Although it was not a widely expressed sentiment, a couple of respondents further expressed the idea that there was a relationship between the absence of taxcollecting organisations and a responsibility on the business to act on behalf of the people. More commonly, a connection was drawn between the need to exhibit self-reliance with the morality required of a business operator or manager. Although respondents did acknowledge that success and all blessings come from Allah, they also believed that their own moral actions could help this to occur. Islamic business ethics, as previously suggested, require the active intervention of individuals when it is required of them to do so. To some extent, the state can take this interventional role when it is the legitimate ruler, but in a civil war the situation becomes fluid and contested. Business owners should not place other people at risk in doing this but should do what they can to preserve the system as far as is possible.

\section{Sectoral differences}

Although the experiences of the respondents were formed and influenced by the same factors, there were some differences between the responses of the managers in either category. The respondents in the banking sector, for example, were more likely to consider their business activities in the context of the whole economy, whilst those in the mobile telecommunications sector tended to be more focused on individual cases. The banking sector respondents were more likely to consider the moral aspects of their actions as serving society as a whole, whilst the mobile telecommunications respondents were more likely to consider morality within the individual relationships that have assumed a different character after the collapse of the central state. Given the nature of the two sectors, it is not surprising that the respondents of one take a macrosocial perspective whilst those of the other take a microsocial one. These are two aspects of managing in adversity, in that some sectors require managers to support the prevailing system from the bottom, by focusing on the needs of individual customers, whilst other sectors require the support of the system from above, by ensuring liquidity and the ability to conduct transactions across the economy. The research design for this project enabled this duality to become evident.

The absence of central institutions had different implications for members of the two sectors. People in mobile telecommunications were able to continue with most of their business activities because the infrastructure required (which is, of course, vulnerable to physical attack) resides with the private sector. This is different for the banking sector because, in this case, necessary infrastructure and support is located in the public sector. That the government is no longer able to collect taxation revenues and provide government services is, therefore, of more concern to this sector than that of mobile telecommunications. To some extent, both these approaches involve the merging of the public and private sectors as contending parties in the war make their compromises and bargains and lend their quasi-state power in the attempt to ensure that private sector activities continue.

Following on from the previous points, it is notable that it was respondents in the mobile telecommunications sector who observed that Somalian people were now more likely to consider business to be the bastion of order and authority that remained and the sole hope of people looking to survive and manage their future. Bankers might look upon themselves in that light but did not include other forms of business in that category. Irrespective of these differences, though, as well as the threat of direct attacks on them, 
respondents in both sectors nevertheless spoke about the sense of responsibility that they felt to people in society. In this sense, then, the violence has brought about a partial and perhaps temporary cessation to the intensification of capital accumulation in the city. However, that accumulation is not in itself seen as wrong but is expected under the ethical system. It will resume whenever conditions permit it to do so.

\section{Discussion}

There is a need to locate the individual fields of experience that people have been undergoing within the overarching power structures that create the world. This power structure is manifested in the war that has been inflicted upon Somalia for some decades. The ostensible causes of intervention in the country by, notably, the United States of America are the presence of the Al Qaeda-linked Al-Shabaab group there and the practice of piracy on ships in the waters off the coast. Actions taken to prevent piracy by security agencies and by shipping companies themselves, forced to act as their insurance providers, caused the attacks to be suppressed for more than 5 years, although risks remain (The Economist, 2017). Suppressing terrorism, on the contrary, has proved to be more problematic, notwithstanding the scale of the resources devoted to the process. An airstrike that was claimed to have killed 60 combatants (Burke, 2018) was followed by a bomb blast in Mogadishu that killed more than 50 people (AFP, 2018). There can be little doubt, therefore, that management as explored in this article took place during wartime. The results indicated that this followed the literature in being composed of three elements: surviving adversity, the use of coping mechanisms and consideration of the ethical issues involved in continuing with business activities in such circumstances.

This is the dominant narrative that is framing the lives of the respondents described in this article and other people who are living in Somalia. It affects every aspect of daily life and, within daily life, the life of work and commerce. A variety of normal life must continue to be practised, but it is a life that is radically disrupted, as it was during the siege of Sarajevo, by the arrival of: '... CNN, NGOs, satellite phones, UN peacekeepers, aid convoys, and diaspora remittances' (Andreas, 2008, p. ix). Certain aspects of daily life have become internationalised, that is, by the changes these arrivals have brought about, but this internationalisation process can be cut off from the majority of the economy, being located in large hotels, press associations, embassies and, for day-to-day movements, isolated within powerful $4 \times 4$ vehicles. The proximity of the external world, which is both present and not present, has an alienating effect on those people still struggling with daily issues. For the respondents in this research, the alienation process has a second face in the disparity between the discourse of business with which the well-educated respondents attempt to describe their interactions with the world and the everyday reality of business being run on premodern lines based on personal relationships and kinship networks. It is not clear how sustainable this is for people to be able to manage. That warfare can lead to the alienation of the individual has been well documented and has been studied in particular in the return of US servicepeople after their defeat in Vietnam (Johnson, 1976). That working in a stressful environment can lead to alienation is also well attested (e.g. Sarros, Tanewski, Winter, Santora, \& Densten, 2002). This research suggests, therefore, a form of double alienation that people might face when working or managing during war that is not constant but that is a constant threat. To deal with this, people demonstrate the use of coping mechanisms that centre on pre-existing tribal methods of governance. This development is broadly in support of the treatment of psychological stress, which focuses on resilience (e.g. Schissel, 1993), as previously suggested. However, this is not to say that there is some form of moral or spiritual relationship with resilience, just as it has been demonstrated by the ongoing coronavirus pandemic that there is no relationship between survival of the virus and moral status. Resilience, after all, was created as a concept '... to offer adaptive solutions without addressing the political roots of contemporary social risk and disaster' (Dawson, 2017, p. 171).

The habitus of the individual is shaped and tempered by these events. It is influenced by a different understanding and use of trust. In contemporary business practice, trust is fostered through a variety of interactions between business and customers, mediated by the integrated marketing communications efforts of the company and the sensitive deployment of new applications with social media networks, preferably on a transparent basis (Schnackenberg \& Tomlinson, 2014). Because of the violence, all of these interactions - or most of them, at least - have been replaced by older forms of trust based on premodern kinship relations. The ability to negotiate the absence of the contemporary paraphernalia of interactivity and to adopt an alternative mode of deal-making has become one of the principal requirements of a manager. This helps managers to survive in a stressful situation because, as it has been argued, although their absolute levels of stress may be higher than employees feel, this is compensated for by the greater agency that managers have to affect the environment around them (Skakon, Kristensen, Christensen, Lund, \& Labriola, 2011). This suggests a level of complexity at a methodological level that the habitus embodies as a container of practices in line with Bourdieu's original concept (Costa \& Murphy, 2015).

Although it may seem likely that the absence of state institutions that both support and regulate companies might act to weaken the relationship between company and community, because there is neither oversight nor restrictions on the firms involved, in fact the opposite is often true. At least according to the testimonies of the respondents, some have felt an increased responsibility to take care of community members by providing needed services, in line with the Islamic business ethics outlined above (Abeng, 1997). This might be linked to the previous point in that a return to a mode of interaction shaped by kinship relations helps to ground individuals within the surrounding community and the responsibilities to them that are incumbent on them, 
which is in accordance with tribal patterns of behaviour (Nenova \& Harford, 2005).

What, then, does this exploration of the commercial life under physical assault indicate for the behaviour of managers in a more general sense? It is possible to propose a model of behaviour that combines the following elements:

- A resurgence of pre-contemporary business practices takes place to replace the contemporary practices, which wither under physical assault.

- Exchange relations are replaced, in part, by social relations that need not be obedient to the market.

- Pragmatism and flexibility replace rule-bound managerial processes.

- Not everyone is able to deal with the cognitive dissonance and alienation that these changes produce.

Further research is necessary to determine the validity of this model in related circumstances. Nevertheless, it is possible to propose this model of management under wartime conditions as a valid approach to understanding this research site.

\section{Conclusion}

This article has explored the management issues facing a group of respondents in Mogadishu in the banking and telecommunications sector. It has been shown that the prevalence of violence and disorder has significantly impacted upon the ability of the managers involved to conduct their business activities according to normal, rational practices. Instead, flexibility, improvisation, morality and the return to premodern tribal relationships have become the new norms. This does not prevent standard business operations, but it does make them more difficult, and it promotes some personal stress amongst people who are unable to bring their education and expectations to bear upon the situation. In these circumstances, it is important for all stakeholders to take a pragmatic attitude towards whatever may be possible that day and the next day and to do it accordingly. Good will is required, although this is difficult to maintain in the presence of intimidation and violence.

As ever, qualitative research such as that reported on in this article is vulnerable to the charge that the findings may have been interpreted differently if a different sample of respondents had been drawn. It also faces the limitation that the experiences of individuals involved may not be comparable and, hence, generalisable to some extent because the impact of the violence may be very different for different people and might change very rapidly. It cannot be guaranteed, for example, that some life-changing event did not affect one or more of the respondents after the start of the research. This is always the case, of course, but here the risks are much higher than in regular management research.

Further research is required to determine the extent to which the current practice of management has been sustained or has either evolved or disintegrated in the period since this research was conducted. It would also be helpful if the research were to be broadened to additional sectors of the economy and to other geographical locations. However, the possibility that this could take place depends upon the security situation, and it is not possible to predict what this will be in the future.

\section{Acknowledgements Competing interests}

The authors have declared that no competing interests exist.

\section{Authors' contributions}

All authors contributed equally to this work.

\section{Ethical consideration}

This article followed all ethical standards for carrying out research without direct contact with human or animal subjects.

\section{Funding information}

This research received no specific grant from any funding agency in the public, commercial or not-for-profit sectors.

\section{Data availability statement}

Data sharing is possible according to standard procedures.

\section{Disclaimer}

The views and opinions expressed in this article are those of the authors and do not necessarily reflect the official policy or position of any affiliated agency of the authors.

\section{References}

Abeng, T. (1997). Business ethics in Islamic context: Perspectives of a Muslim business leader. Business Ethics Quarterly, 7(3), 47-54. https://doi.org/10.2307/3857312

Agence France-Press (AFP). (2018, November 18). Death toll from Somali bomb blast rises above 50. The Guardian. Retrieved from https://www.theguardian.com/ world/2018/nov/11/death-toll-from-somali-bomb-blasts-rises-above-50.

Aleksić, A., Stefanović, M., Arsovski, S., \& Tadić, D. (2013). An assessment of organizational resilience potential in SMEs of the process industry, a fuzzy approach. Journal of Loss Prevention in the Process Industries, 26(6), 1238-1245. https://doi.org/10.1016/j.jp.2013.06.004

Ali, A.Y.S., \& Dahie, A.M. (2015). Leadership style and teacher job satisfaction: Empirical study from secondary schools in Somalia. Research on Humanities and Social Sciences, 5(8), 84-96.

Ali, A.Y.S., Sidow, M.A., \& Guleid, H.S. (2015). Leadership styles and job satisfaction: Empirical evidence from Mogadishu universities. European Journal of Management Sciences and Economics, 1(1), 1-10.

Anderson, P. (2017). Passing the baton. New Left Review, (103), 41-64.

Andreas, P. (2008). Blue helmets and black markets: The business of survival in the siege of Sarajevo. Ithaca, NY: Cornell University Press.

Annarelli, A., \& Nonino, F. (2016). Strategic and operational management of organizational resilience: Current state of research and future directions. Omega, 62, 1-18. https://doi.org/10.1016/j.omega.2015.08.004

Bourdieu, P. (1998). Practical reason. Cambridge: Polity.

Bourdieu, P., \& Wacquant, L.J.D. (1992). An invitation to reflexive sociology. Cambridge: Polity.

Brook, T. (2007). Collaboration: Japanese agents and local elites in wartime China. Cambridge, MA: Harvard University Press.

Burke, J. (2018, October 16). Airstrike kills 60 Islamist extremist fighters in Somalia, US military says. The Guardian. Retrieved from https://www.theguardian.com/ world/2018/oct/16/somalia-us-military-airstrike-al-shabaab. 
Business Wire. (2019, November 15). Somalia telecoms, mobile and broadband statistics and analyses report 2019 - ResearchandMarkets.com. Retrieved from https://www.businesswire.com/news/home/20191115005357/en/Somaliahttps://www.businesswire.com/news/home/201911.

Costa, C., \& Murphy, M. (2015). Bourdieu and the application of habitus across the social sciences. In C. Costa \& M. Murphy (eds.), Bourdieu, habitus and social research (pp. 3-17). London: Palgrave Macmillan.

Dawson, A. (2017). Extreme cities: The perils and promise of urban life in the age of climate change. London: Verso.

Debiel, T., Glasner, R., Schetter, C., \& Terlinden, U. (2009). Local state-building in Afghanistan and Somaliland. Peace Review: A Journal of Social Justice, 21(1), 38-44. https://doi.org/10.1080/10402650802690052

Englebert, P., \& Tull, D.M. (2008). Postcolonial reconstruction in Africa: Flawed ideas about failed states. International Security, 22(4), 106-139. https://www.jstor.org/ stable/30129793.

Fusch, P.I., \& Ness, L.R. (2015). Are we there yet? Data saturation in qualitative research. The Qualitative Report, 20(9), 1408-1416.

Hauff, J.C. (2019). Reasons to switch: Empowered vs less powerful bank customers International Journal of Bank Marketing, 37(6), 1441-1461. https://doi. org/10.1108/IJBM-08-2018-0231

Hoekstra, S., \& Montz, B. (2017). Decisions under duress: Factors influencing emergency management decision making during Superstorm Sandy. Natural Hazards, 88(1), 453-471. https://doi.org/10.1007/s11069-017-2874-7

Hsieh, H.-F., \& Shannon, S.E. (2005). Three approaches to qualitative content analysis. Qualitative Health Research, 15(9), 1277-1288. https://doi.org/10.1177/ 1049732305276687

Johnson, L. (1976). Political alienation among Vietnam veterans. The Western Political Quarterly, 29(3), 398-409. https://doi.org/10.2307/447512

Jones, B.G. (2008). Towards a critique of the 'failed state' ideology. Review of International Political Economy, 15(2), 180-205. https://doi.org/10.1080/ 09692290701869688

Kakabadse, N.K., Rozuel, C., \& Lee-Davis, L. (2005). Corporate social responsibility and stakeholder approach: A conceptual review. International Journal of Business Governance and Ethics, 1(4), 277-302. https://doi.org/10.1504/ IJBGE.2005.006733

Kuttab, E. (1989). Community development under occupation: An alternative strategy. Journal of Refugee Studies, 2(1), 131-138. https://doi.org/10.1093/jrs/2.1.131

Lehtinen, J., Aaltonen, K., \& Rajula, R. (2019). Stakeholder management: Complex product systems, practices and rationales for engagement and disengagement. Industrial Marketing Management, 19, 58-70. https://doi.org/10.1016/j. indmarman.2018.08.011

Lengnick-Hall, C.A., Beck, T.E., \& Lengnick-Hall, M.L. (2011). Developing a capacity for organizational resilience through strategic human resource management. Human Resource Management Review, 21(3), 243-255. https://doi.org/10.1016/j. hrmr.2010.07.001

Levine, R., Lin, C., \& Xie, W. (2018). Corporate resilience to banking crises: The roles of trust and trade credit. Journal of Financial and Quantitative Analysis, 53(4) 1441-1477. https://doi.org/10.1017/S0022109018000224

Linnenluecke, M.K., Griffiths, A., \&Winn, M. (2012). Extreme weather events and the critical importance of anticipatory adaptation and organizational resilience in responding to impacts. Business Strategy and the Environment, 21(1), 17-32. https://doi.org/10.1002/bse.708

Mallak, L. (1998). Putting organizational resilience to work. Industrial Management, $40(6), 8-13$
Marchese, S.-E., \& Ratcliffe, R. (2018, September 03). 'I get scared, but I'm staying'; poignant words of murdered Mogadishu florist. The Guardian. Retrieved from https://www.theguardian.com/global-development/2018/sep/03/poignantwords-of-murdered-mogadishu-florist-mohamed-mahamoud-sheik.

Nastasi, B.K., \& Schensul, S.L. (2005). Contributions of qualitative research to the validity of interventional research. Journal of Social Psychology, 43(3), 177-195. https://doi.org/10.1081/JA-200033233

Nenova, T., \& Harford, T. (2005). Anarchy and invention: How does Somalia's private sector cope without government? Africa Region Findings \& Good Practice Infobriefs, 254. Retrieved from https://openknowledge.worldbank. org/handle/10986/9655.

Renner, R.A. (2004). America's asymmetric advantage: The utility of airpower in the new strategic environment. Defence Studies, 4(1), 87-113. https://doi. org $/ 10.1080 / 1470243042000255281$

Robinson, O.C. (2014). Sampling in interviewer based qualitative research: A theoretical and practical guide. Qualitative Research in Psychology, 11(1), 25-41. https://doi.org/10.1080/14780887.2013.801543

Samator, A.I. (1992). Destruction of state and society in Somalia: Beyond the tribal convention. The Journal of Modern African Studies, 30(4), 625-641. https://doi. org/10.1017/S0022278X00011083

Sarros, J.C., Tanewski, G.A., Winter, R.P., Santora, J.C., \& Densten, I.L. (2002). Work alienation and organizational leadership. British Journal of Management, 13(4) 285-304. https://doi.org/10.1111/1467-8551.00247

Sayid, O., Echchabi, A., \& Aziz, H.A. (2012). Investigating mobile money acceptance in Somalia: An empirical study. Pakistan Journal of Commerce and Social Sciences, 6(2), 269-281.

Schissel, B. (1993). Coping with adversity: Testing the origins of resiliency in mental health. International Journal of Social Psychiatry, 39(1), 34-46. https://doi. org $/ 10.1177 / 002076409303900104$

Schnackenberg, A.K., \& Tomlinson, E.C. (2014). Organizational transparency: A new perspective on managing trust in organization-stakeholder relationships. Journal of Management, 42(7), 1784-1810. https://doi.org/10.1177/0149206314525202

Skakon, J., Kristensen, T.S., Christensen, K.B., Lund, T., \& Labriola, M. (2011). Do managers experience more stress than employees: Results from the Intervention Project on Absence and Well-Being (IPAW) study among Danish managers and their employees. Work, 38(2), 103-109. https://doi.org/10.3233/WOR-2011 1112

Staniland, P. (2012). States, insurgents, and wartime political orders. Perspectives on Politics, 10(2), 243-264. Retrieved from https://www.jstor.org/stable/41479550.

The Economist. (2017, April 12). Why Somali piracy is staging a comeback? Retrieved from https://www.economist.com/the-economist-explains/2017/04/18/whysomali-piracy-is-staging-a-comeback.

Vallascas, F., \& Keasey, K. (2012). Bank resilience to systemic shocks and the stability of banking systems: Small is beautiful. Journal of International Money and Finance, 31(6), 1745-1776. https://doi.org/10.1016/j.jimonfin.2012.03.011

Walsh, J. (2012). Economic geography in the development of Cambodia: The case of Okhna Mong Port Co. Ltd. International Journal of Business and Globalisation, 9(3), 236-245. https://doi.org/10.1504/IJBG.2012.050364

Walsh, J. (2016). Casino resorts as micro-para-statal areas in the GMSR: Connectivity and economic development. The Myanmar Journal, 3(1), 21-31.

Wehr, P., \& Lederach, J.P. (1991). Mediating conflict in Central America. Journal of Peace Research, 28(1), 85-98. https://doi.org/10.1177/0022343391028001009

World Bank. (2018). Overview: Helping countries navigate a volatile environment. Retrieved from www.worldbank.org/en/topic/fragility/conflictviolence/overview. 